\title{
Thermal comfort analysis in the sustainable educational building
}

\author{
Luiza Dębska ${ }^{1, *}$, and Justyna Krakowiak ${ }^{1}$ \\ ${ }^{1}$ Kielce University of Technology, Faculty of Environmental Geomatic and Energy Engineering, 7 aleja Tysiąclecia Państwa Polskiego, \\ 25-314 Kielce, Poland
}

\begin{abstract}
In the modern world, a person spends most of his life indoors. That is why it is so important to create optimal conditions for the internal environment. Research on thermal comfort and subjective feeling of people inside the building can help in this. The article discusses two methods that are used in research on thermal sensations. This makes it possible to know the thermal assessment of people and then compare this result with the calculated PMV value, which is calculated using the formula from ISO 7730 standard.
\end{abstract}

\section{Introduction}

Today, energy consumption is one of the main problems of the modern world. A solution to this problem is sought in energy-efficient construction, which uses various types of renewable energy sources, such as solar collectors, photovoltaic cells, heat pumps, wind turbines, biofuels or hybrid solutions. Moreover, such buildings belong to sustainable construction, whose main goal, apart from the use of devices for the production of renewable energy, is to reduce waste and pollution generated during the construction of ecological buildings in such a way as to minimize interference with the environment. Another advantage is definitely the cost of maintaining such a building, because the building works on itself, it is selfsufficient. In addition, the idea of sustainable construction is to reduce the consumption of water, electricity, heat losses, create appropriate conditions for the internal environment, including air exchange with the help of well-selected ventilation, use containers for waste segregation and create optimal conditions and thermal comfort for people who spend most of their lives indoors [1-6]. At this point, a lot of research into thermal comfort is carried out. An example of such research is a study by Hwang et al. [7] who analyzed 944 people at universities in Taiwan. The respondents definitely determined that the best temperatures in which they feel are in the range of $21.1^{\circ} \mathrm{C}$ to $29.8^{\circ} \mathrm{C}$ and $24.2^{\circ} \mathrm{C}$ to $29.8^{\circ} \mathrm{C}$. In Australia, Dear and others have attempted to forfeit both primary and secondary school students. During the research, 2,850 questionnaires were received. After analyzing the questionnaires, the results were obtained in which the respondents defined their thermal sensations in the range of 19 -26. Later, these studies were extended to include more results. Kim and Dear [8-9] have further decided to forfeit the school environment. From the obtained results, the authors found out that students prefer cooler temperatures, and more of the received questionnaires, students who had the option of using air conditioning during classes were better adapted to it than children who did not have such an opportunity. Zaki et al [10] analyzed three universities - two in Malaysia and one in Japan, over the summer. 1428 surveys were thoroughly analyzed, which showed that in Japan the best temperature was $25.1^{\circ} \mathrm{C}$, while in Malaysia it was $25.6^{\circ} \mathrm{C}$. In Indonesia, Hamzah et al. [11] perished Hasanuddin University in Gowa. The thermal sensations during the research were described by 118 people, from whom it appears that these guards felt comfortable in selected rooms. Liu et al.[12] analyzed naturally ventilated rooms in northwest China, in the city of Xi'an, to see how the students living in these rooms feel thermal. A total of 992 questionnaires were completed, which showed that the most natural temperature was $20.6^{\circ} \mathrm{C}$, and the range in which the students determined their thermal comfort was the temperature from $19.5^{\circ} \mathrm{C}$ to $21.8^{\circ} \mathrm{C}$, and the preferred temperature was $22.7^{\circ} \mathrm{C}$. In Brazil, at the University of Goias, Abreu-Harbich et al. [13] investigated classrooms with three air conditioning methods such as natural ventilation, evaporative cooling, and air conditioning. The authors wanted to get to know the students' thermal feelings, because the discomfort in the classrooms might have compromised their knowledge. 200 people were lost. $69.52 \%$ of people definitely did not correspond to the creature conditions by natural ventilation. Less, because only $60.67 \%$ were dissatisfied with evaporative cooling and $70.18 \%$ of the respondents did not accept the conditions of the internal environment created by air conditioning. Moreover, the neutral temperature was set at $25.9^{\circ} \mathrm{C}$. Buonocore et al. [14] at the University of Sao Luis, Brazil, analyzed the subjects' thermal preferences and the feeling of thermal comfort. The rooms covered by the study were air-conditioned and ventilated in a natural way. The authors of these studies wanted to know the appropriate climatic conditions in the internal environment of the room. Therefore, the city of Sao Luis was chosen for its location in an equatorial climate where it is hot and humid. The problem of local students is overcooling associated with the excessive use of air

\footnotetext{
* Corresponding author: 1debska@tu.kielce.pl
} 
conditioning in the classrooms. From the questionnaires completed by students it was concluded that the best conditions meeting the preferences of the respondents were the temperature range from $23^{\circ} \mathrm{C}-24^{\circ} \mathrm{C}$. It was in this respect that the students felt thermal comfort. Moreover, they tended to increase the temperature to $26^{\circ} \mathrm{C}$. About $20 \%$ of respondents felt discomfort if the temperature was lower than 22, with a clo of 0.3 . Guevara et. Al. [15] have taken an analysis of three cities in Ecuador - Quito, Guayaquil, and Tena. From December 2017 to January 2018, the authors of the study received 429 questionnaires completed by volunteers. The aim of this research was to obtain information about the thermal comfort of people living in the tropics, where the weather is very changeable. Neutral temperatures in which the respondents felt best were in turn $21.8^{\circ} \mathrm{C}, 26.3^{\circ} \mathrm{C}$ or $26.9^{\circ} \mathrm{C}$. The respondents from Guayaquil and Tena were directed to cool temperatures because of the hot and humid climate in their areas of residence. In Bangladesh, a study was performed in the summer of 2017 by Talukdar and others [16]. They focused on learning about the thermal preferences of students in naturally ventilated rooms. 579 sheets with respondents' answers were received. The parameters maintained during the test were equal to the temperature $-30.9^{\circ} \mathrm{C}$, humidity $-78.4 \%$ and the wind speed $-0.8 \mathrm{~m} / \mathrm{s}$. After the analysis, it was found that the best neutral temperature for the feeling of thermal comfort is $27.8^{\circ} \mathrm{C}$. Abdallah [17] conducted research at the Assiut University. The study covered 6 naturally ventilated classrooms. Initially, 331 people participated in the study, but after an in-depth analysis, only 269 questionnaires remained. It was concluded from the responses that the temperature exceeded $28^{\circ} \mathrm{C}$, which was met with discomfort by students in $90 \%$. At the Bahia Federal University in Salvador, Brazil, Costa and others [18] analyzed the students' thermal sensations. Only 53\% of the respondents felt thermal comfort. The conclusion of these studies was the incorrect maintenance of the condition of windows and window frames, which prevented the correct flow of air between the external and internal environment. In Thailand, the University tested 3 speeds of the air conditioner - low, medium and high, then the students completed the questionnaires. Puangmalee et al [19] analyzed the results of the surveys which concluded that students would be able to accept a temperature of 28 as long as the air conditioner speed could be regulated. Additionally, the information was obtained that the higher the speed, the higher the neutral temperature.

An educational and laboratory building of Environmental Engineering, Kielce University of Technology, called „Energis” from the year 2012, is such an energy-saving and intelligent building. "Energis" has been designed with sustainable construction in mind. The main and set goal was to monitor the effects of energy saving, the balance of energy gains and losses, maintaining appropriate parameters of the internal environment while using the most modern automation and control solutions for devices such as photovoltaic cells, solar panels, heat pumps, energy storage [20, 21]. Figure 1 presents a photo of the "Energis" building and shows the selected room where the research on thermal comfort of students of Kielce University of Technology was conducted.

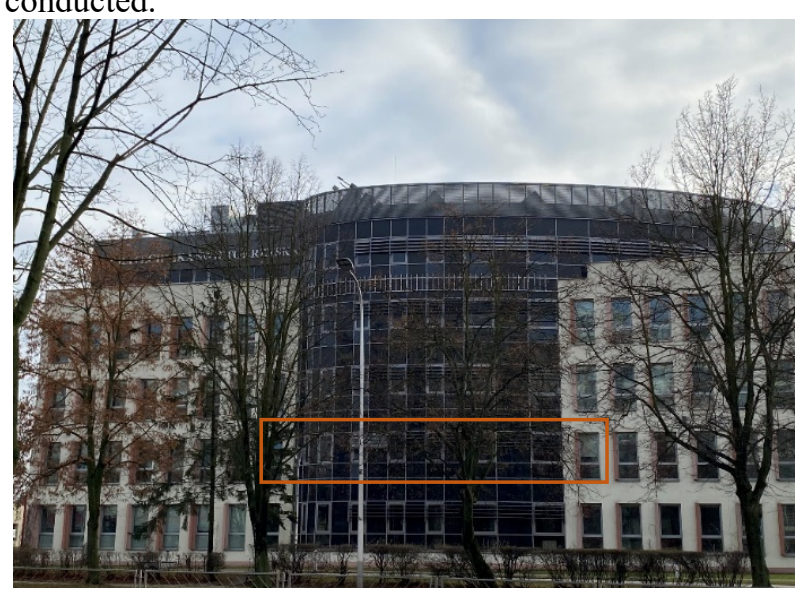

Fig. 1. Photo of "Energis" building and selected room where the test was performed.

\section{Testing methods}

Thermal comfort measurements are divided into two methods, indirect and direct. The indirect method is based on the analysis of completed questionnaires by people in the room covered by the study and direct method aimed at obtaining microclimate parameters using a meter (air temperature, globe temperature probe, air velocity, relative humidity, light intensity). These data, in particular temperature, air velocity and humidity are needed to calculate the PMV (Predicted Mean Vote) from the formula contained in the ISO 7730 standard [22, 23].

The questionnaire included questions about thermal sensations, adequacy of temperature, sensations of humidity, current clothing and physical activity, as assessed by study volunteers. A very important fact when assessing the thermal sensations of test volunteers is to check what physical activity they had before the test. People who did not perform any physical activity, i.e. sat before the test, or walked for no more than 10 minutes, are a reliable source of information about their thermal sensations. If, on the other hand, such people did strength training a moment before the measurement, unfortunately such people may distort the picture of knowing their thermal preferences. Thus, polls must be rejected. Additionally, the actual thermal sensation is also influenced by clothing, otherwise known as the clothing thermal isolation (clo), which for this group was 0,62. Note that if the subject is dressed too warm, he may feel discomfort in the form of heat. Similarly, she will feel bad wearing summer clothes, and the room will be too cold. To measure the internal environment, a Testo 400 meter was used located in the middle of the lecture hall. After 15 minutes, when the values had stabilized, they were collected and recorded. Meanwhile, the volunteers completed the questionnaires. The purpose of using two these methods is to check whether the conditions in the room create thermal comfort for the occupants. Figure 2 and figure 3 below show the meter with a description of the probes collecting the necessary parameters (globe 
temperature probe, light intensity probe, turbulence probe, $\mathrm{CO}_{2}$ probe, temperature and humidity probe).

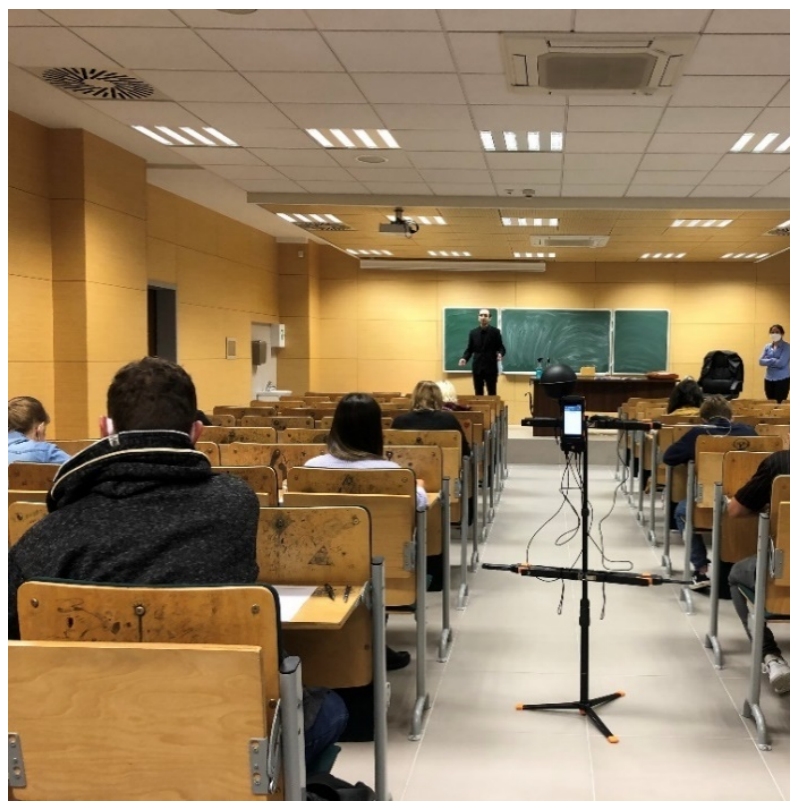

Fig. 2. Location of the measuring station in the lecture hall and probes measuring the conditions in the room.

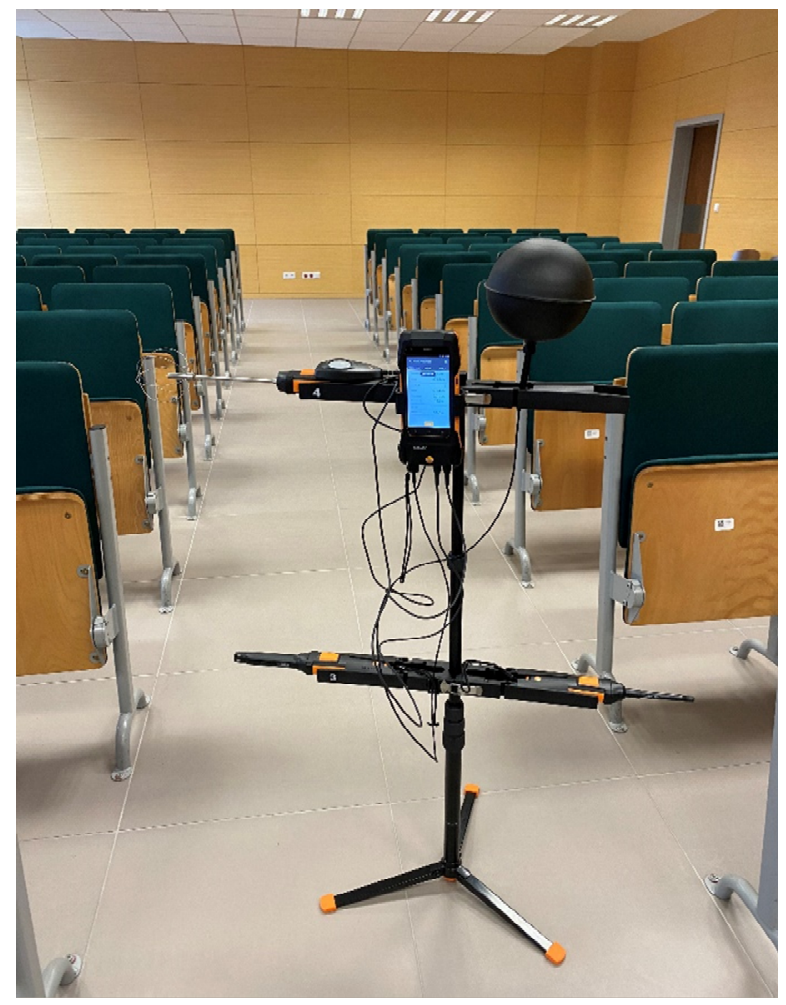

Fig. 3. The meter of Testo 400.

\section{Test result}

In the selected room where examination was performed, there is mechanical ventilation with adjustable parameters, which was activated during the examination. Table 1 shows the obtained results of the conditions in the tested room with the use of a meter Testo 400.
Table 1. Parameters of the internal environment obtained with the use of the meter.

\begin{tabular}{|l|l|}
\hline Air temperature $\left[{ }^{\circ} \mathrm{C}\right]$ & 25.7 \\
\hline Black ball temperature $\left[{ }^{\circ} \mathrm{C}\right]$ & 25.2 \\
\hline Relative humidity $[\%]$ & 56,6 \\
\hline Air Velocity $[\mathrm{m} / \mathrm{s}]$ & 0.43 \\
\hline
\end{tabular}

In the study involved 9 people in the age range from 21-24 years. Figure 4 below shows the thermal feelings of the respondents as TSV (thermal sensation votes).

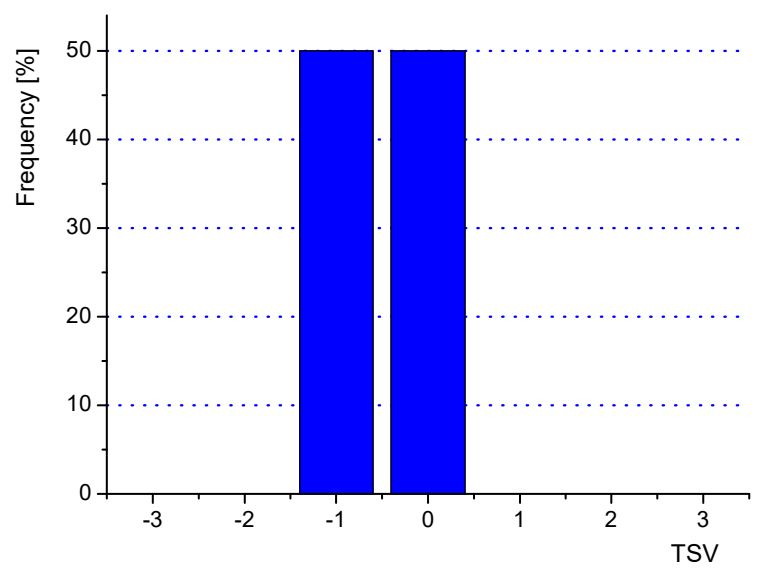

Fig. 4. Voices of the respondents concerning the thermal sensation: -3 - too cold, -2 - too cool, -1 - pleasantly cool, $0-$ comfortable, 1 - pleasantly warm, 2 - too warm, 3 - too hot.

$50 \%$ of respondents consider that the room in pleasantly cool. The other half, i.e. $50 \%$ of people described their thermal sensations as comfortable. Figure 5 below shows the group's responses to the feeling of accepting the current temperature in the tested room (TAV - thermal acceptability vote).

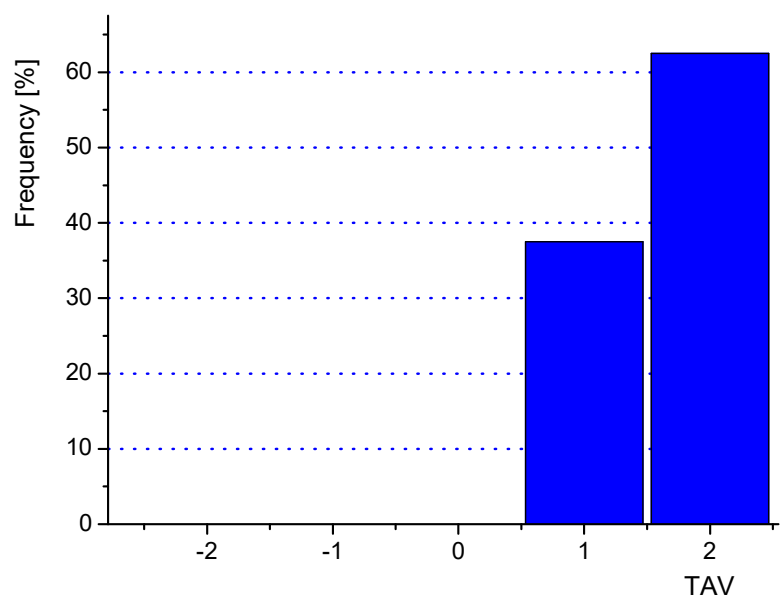

Fig. 5. Acceptance of temperature according to the volunteers: -2 - definitely unpleasant, -1 - unpleasant, 1 - acceptable, 2 comfortable.

$37.5 \%$ of people in the study group consider that the temperature is still acceptable, while $62.5 \%$ of people described their feelings of temperature as comfortable. Figure 6 shows the responses of individual thermal 
preferences (TPV - thermal preference vote) in relation to change in air temperature.

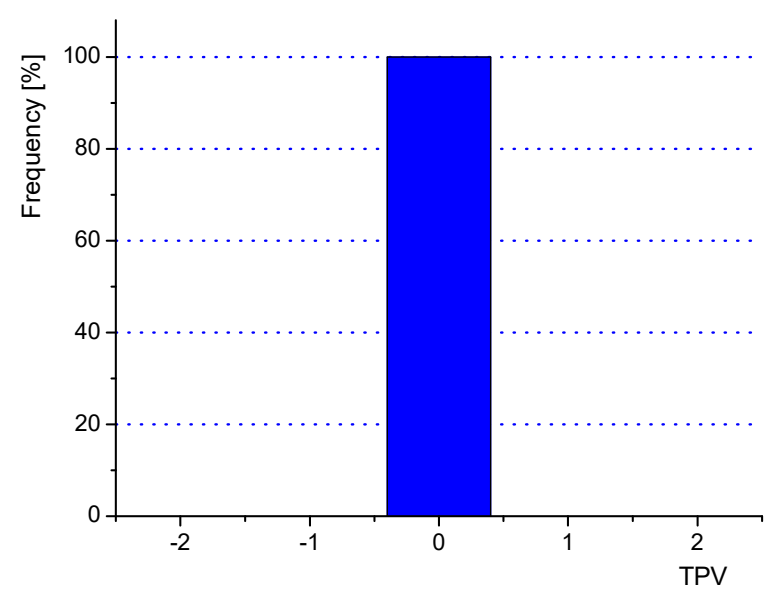

Fig. 6. Thermal preferences vote: $-2-$ definitely cooler, $-1-$ cooler, 0 - no change, 1 - warmer, 2-definitely warmer.

$100 \%$ of people would not want to change the temperature to a cooler or warmer temperature. This proves that the prevailing temperature in the room was so favorable that the whole group of eight felt thermal comfort. Figure 7 below shows the assessment of humidity by the tested group.

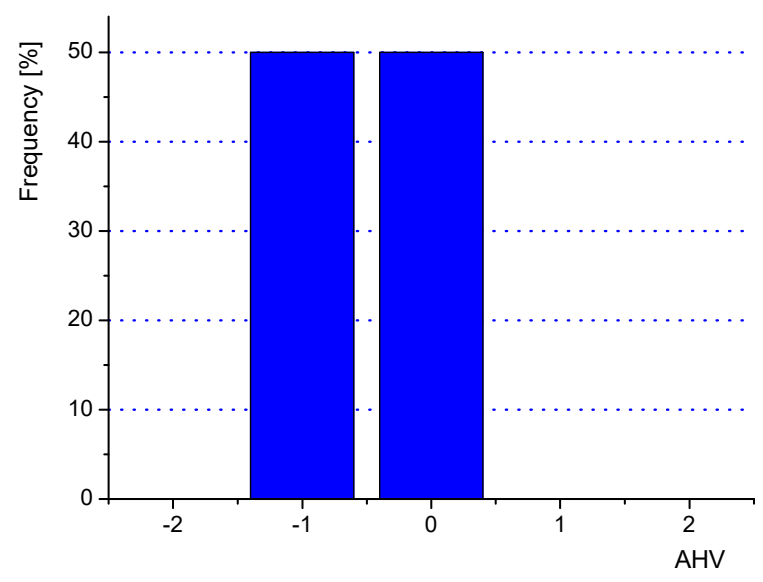

Fig. 7. Assessment of humidity according to the respondents: -2 - too dry, -1 - quite dry, 0 - pleasantly, 1 quite humid, 2 - too humid

$50 \%$ of people rated the humidity as pleasant. The other half of the group, i.e. $50 \%$ of respondents, think that the room is quite dry. The graph of the humidity preference responses by the volunteers is shown on figure 8 .

In the studied group, $75 \%$ of people would not like to a change in air humidity, as opposed to $25 \%$ of people who would definitely like it to be more humid. Figure 9 shows the relationship between the PMV index and the BMI mass index in order to determine if this parameter had any impact on the obtained results.

According to the figure the higher the BMI index of a person, the warmer they feel. It confirms a generally accepted view and might have a slight impact on the obtained experimental results.

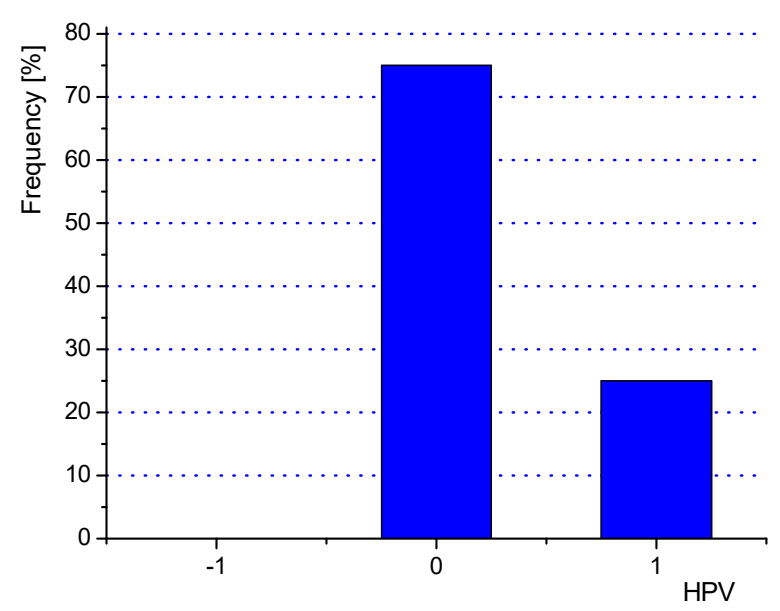

Fig. 8. Frequency of answers humidity preferences vote: $-1-$ more dry, 0 - no change, 1 - more humid.

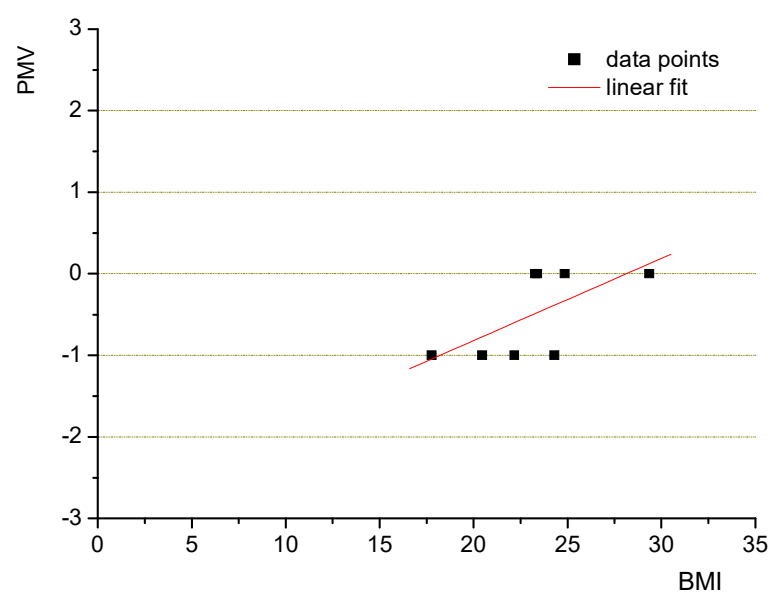

Fig. 9. The relationship between the PMV index and the BMI mass index.

\section{Conclusions}

To sum up, from the obtained results, it can be concluded that the room meets the expectations of its occupants in the modern "Energis" intelligent building. Thus, such a construction that meets the criteria for the sustainable building is a user - friendly educational building. The temperature there was perceived as comfortable and pleasant, therefore none of the respondents would like to change the prevailing temperature to a warmer or cooler one. Likewise for the humidity where it was found to be pleasant and fairly dry. $75 \%$ of the group would not want the humidity settings changed except for the $25 \%$ which specified it could be more humid. The conclusion is obvious that the ventilation in this room has well-chosen parameters that ensure well-being in the external environment.

In the future, research on thermal comfort will be carried out in order to better understand the individual thermal preferences of people indoors. 


\section{References}

1. L. Zitzman, Sustainable Construction: Methods and Benefits.

https://www.bigrentz.com/blog/sustainable-

construction (2020). Accessed 21 Mar 2021

2. Co to jest zrównoważone budownictwo? https://jwa.pl/2019/06/co-to-jest-zrownowazone-

budownictwo/ (2019). Accessed 21 Mar 2021

3. Budownictwo zrównoważone. https://architektura.info/architektura_zrownowazona /zielone_innowacje2/budownictwo_zrownowazone (2013). Accessed 21 Mar 2021

4. G. Majewski, Ł.J. Orman, M. Telejko, N. Radek, J. Pietraszek, A. Dudek, Assessment of thermal comfort in the intelligent buildings in view of providing high quality indoor environment. Energies 13(8), 1973 (2020). doi:10.3390/en13081973.

5. Zimny J.; Odnawialne źródła energii w budownictwie niskoenergetycznym. Wyd. Wydawnictwo Nukowo-Techniczne, Warszawa 2010. ISBN 978-83-7490-378-3

6. How can renewable energy be used in the built environment? https://arena.gov.au/renewableenergy/renewables-in-buildings/ (2020). Accessed 21 Mar 2021

7. R.-L. Hwang, T.-P. Lin, N.-J. Kuo, Field experiments on thermal comfort in campus classrooms in Taiwan. Energy and Buildings 38, 53-62 (2006). doi:10.1016/j.enbuild.2005.05.001

8. R. de Dear, J. Kim, C. Candido, M. Deuble, Adaptive thermal comfort in Australian school classrooms. Building Research \& Information 43, 383-398 (2015). doi:10.1080/09613218.2015.991627

9. J. Kim, R. de Dear, Thermal comfort expectations and adaptive behavioural characteristics of primary and secondary school students. Building and Environment 127, 13-22 (2018). doi:10.1016/j.buildenv.2017.10.031

10. S.A. Zaki, S.A. Damiati, H.B. Rijal, A. Hagishima, A.A. Razak, Adaptive thermal comfort in university classrooms in Malaysia and Japan. Building and Environment 122, 294-306 (2017). doi:10.1016/j.buildenv.2017.06.016

11. B. Hamzah, M.T. Ishak, S. Beddu, M.Y. Osman, Thermal comfort analyses of naturally ventilated university classrooms. Structural Survey 34, 427-445 (2016). doi:10.1108/SS-12-2015-0055

12. J. Liu, X. Yang, Q. Jiang, Y. Liu, Occupants' thermal comfort and perceived air quality in natural ventilated classrooms during cold days. Building and Environment 158, 73-82 (2019). doi:10.1016/j.buildenv.2019.05.011

13. L.V. de Abreu-Harbich, V.L.A. Chaves, M.C.G.O. Brandstetter, Evaluation of strategies that improve the thermal comfort and energy saving of a classrooms of an institutional building in a tropical climate. Building and Environment 135, 257-268 (2018). doi:10.1016/j.buildenv.2018.03.017

14. C. Buonocore, R. De Vecchi, V. Scalco, R. Lamberts, Thermal preference and comfort assessment in airconditioned and naturally-ventilated university classrooms under hot and humid conditions in Brazil. Energy and Buildings 211 (2020)

15. G. Guevara, G. Soriano, I. Mino-Rodriguez, Thermal comfort in university classrooms: An experimental study in the tropics. Building and Environment 187 (2021). doi:10.1016/j.buildenv.2020.107430

16. S.J. Talkudar, T.H. Talukdar, M.K. Singh, A. Baten, S. Hossen, Status of thermal comfort in naturally ventilated University classrooms of Bangladesh in hot and humid summer season. Journal of Building Engineering $\quad 32$ doi:10.1016/j.jobe.2020.101700

(2020).

17. A. S. H. Abdallah, Analysis of Thermal Comfort and Energy Consumption in Long Time Large Educational Halls (Studios), Assiut University, Egypt. Procedia Engineering 121, 1674-1681 (2015). doi:10.1016/j.proeng.2015.09.115

18. M.L. Costa, M.R. Freire, A. Kiperstok, Strategies for thermal comfort in University buildings - The case of the faculty of architecture at the Federal University of Bahia, Brazil. Journal of Environmental Management 239, 114-123 (2019). doi:10.1016/j.jenvman.2019.03.004

19. N. Puangmalee, K. Hussaro, V. Boonyayothin, J. Khedari, A field of the Thermal Comfort in University Buildings in Thailand under Air Condition Room. Energy Procedia 79, 480-485 (2015). doi:10.1016/j.egypro.2015.11.522

20. Energis - Educational and Laboratory building of Environmntal engineering, Kielce, University of Technology.

http://energis.tu.kielce.pl/index.php/krotki_opis_proj ektu

21. Energis - to inteligentny, energooszczędny, zasilany z odnawialnych źródeł energii nowy budynek Politechniki Świętokrzyskiej. https:/www.ncbr.gov.pl/ocentrum/aktualnosci/szcze goly-aktualnosci/news/energis-to-inteligentnyenergooszczedny-zasilany-z-odnawialnych-zrodelenergii-nowy-budynek-poli/

22. P.O. Fanger, Komfort cieplny (Arkady, Warszawa, 1974)

23. ISO International Organisation for Standardization, Ergonomics of the thermal environment - Analytical determination and interpretation of thermal comfort using calculation of the PMV and PPD indices and local thermal comfort criteria, International Standard ISO 7730, 2005. 